DOI: $10.19195 / 0137-1134.114 .1$

BARBARA ADAMIAK

Uniwersytet Wrocławski

barbara.adamiak@uwr.edu.pl

\title{
DOMNIEMANIE PRAWIDŁOWOŚCI MILCZĄCEGO ZAŁATWIENIA SPRAWY
}

\begin{abstract}
Abstrakt: Milczące załatwienie sprawy wchodzi do obrotu prawnego w dniu następnym po dniu, w którym upływa termin przewidziany do wydania decyzji lub postanowienia kończącego postępowanie w sprawie albo wniesienia sprzeciwu (art. 122c $§ 1$ k.p.a.). Milczące załatwienie sprawy nabywa przymiotu ostatecznego załatwienia sprawy. Zgodnie z art. 122g in fine k.p.a.: „Przyjmuje się, że skutek wydania decyzji ostatecznej powstał w terminie czternastu dni od dnia upływu terminu, o którym mowa w art. $122 \mathrm{c} \S 1$ ".

Milczące załatwienie sprawy obowiązuje w obrocie prawnym, wiążąc zarówno organ administracji publicznej, jak i stronę (strony). Milczące załatwienie sprawy korzysta z ochrony trwałości, obowiązując w obrocie prawnym jako rozstrzygnięcie sprawy zgodne z przepisami prawa. Podważenie trwałości milczącego załatwienia sprawy może nastąpić przez obalenie domniemania prawidłowości na podstawie przepisów prawa w trybach przewidzianych dla weryfikacji decyzji i w wyniku kontroli wykonania decyzji mających zastosowanie do milczącego załatwienia sprawy (art. 122g k.p.a.).
\end{abstract}

Słowa kluczowe: milczące załatwienie sprawy, domniemanie prawidłowości, trwałość, granice trwałości, tryby weryfikacji

\section{DOMNIEMANIE PRAWIDŁOWOŚCI JAKO CECHA WŁADCZEGO DZIAŁANIA ADMINISTRACJI PUBLICZNEJ}

Zgodnie z art. 7 Konstytucji Rzeczypospolitej Polskiej „Organy władzy publicznej działają na podstawie i w granicach prawa”. Konstytucyjna zasada praworządności ograniczająca swobodę działania organów administracji publicznej obowiązującymi przepisami prawa w zakresie podstawy, formy, treści i trybu jest argumentem przyjęcia na podstawie obowiązującego systemu prawnego koncepcji przypisania działaniu organów administracji publicznej cechy domniemania prawidłowości działania ${ }^{1}$. Przypisanie tej cechy działaniu organów administracji

1 W doktrynie prawa administracyjnego przypisanie cechy domniemania prawidłowości działania organów administracji publicznej wyprowadzane jest z instytucji władztwa administracyjnego. 
publicznej ma podwójny skutek mocy obowiązującej tego działania przez związanie organów państwa, ale też jednostek, wobec których to działanie ma następstwa w zakresie uprawnień lub obowiązków.

W doktrynie prawa procesowego z uogólnienia rozwiązań prawnych wyprowadza się zasadę domniemania prawidłowości decyzji administracyjnej ${ }^{2}$. Organy administracji publicznej, zgodnie z art. 6 k.p.a. ${ }^{3}$, związane zasadą praworządności, rozpoznając i rozstrzygając sprawę indywidualną decyzją administracyjną, działają na podstawie przepisów prawa. Związanie organu administracji publicznej zasadą praworządności uzasadnia domniemanie, że zasada ta została zastosowana przy rozpoznaniu i rozstrzygnięciu sprawy indywidualnej w decyzji administracyjnej. Decyzja administracyjna jest zatem prawidłowa i jako zgodna $\mathrm{z}$ prawem wchodzi do obrotu prawnego i w tym obrocie prawnym obowiązuje. Przypisanie cechy domniemania prawidłowości decyzji administracyjnej wynika wprost z zasady ogólnej trwałości decyzji ostatecznej. Według art. 16 § 1 k.p.a. „Decyzje, od których nie służy odwołanie w administracyjnym toku instancji lub wniosek o ponowne rozpatrzenie sprawy, są ostateczne. Uchylenie lub zmiana takich decyzji, stwierdzenie ich nieważności oraz wznowienie postępowania może nastąpić tylko w przypadkach przewidzianych w kodeksie lub ustawach szczególnych". Decyzja administracyjna obowiązuje w obrocie prawnym jako decyzja zgodna z prawem. Obalenie tego domniemania nastąpić może wyłącznie w przewidzianych przepisami prawa trybach nadzwyczajnych. Niepodjęcie skutecznej weryfikacji, a zatem takiej, której następstwem jest przy ciężkim kwalifikowanym naruszeniu prawa zastosowanie sankcji nieważności, a przy innego rodzaju naruszeniu przepisów prawa zastosowanie sankcji wzruszalności, decyzja administracyjna zachowuje moc obowiązującą, wywołując skutki prawne decyzji zgodnej z przepisami prawa.

Moc cechy domniemania prawidłowości decyzji administracyjnej wzmacnia regulacja drugiej cechy, cechy prawomocności. Według art. $16 \S 3$ k.p.a. „Decyzje ostateczne, których nie można zaskarżyć do sądu, są prawomocne". Przypisaniem cechy prawomocności decyzji ostatecznej należy objąć zarówno wyłączenia dopuszczalności zaskarżenia do sądu administracyjnego, jak i do sądu powszechnego (art. 269 k.p.a.). Ma to następstwa prawne dla dopuszczalności trybów nadzwyczajnych, a zatem możliwości prawnej obalenia domniemania prawidłowości decyzji administracyjnej po wyłączeniu drogi sądowej.

Zob. J. Borkowski, Określenie administracji i prawa administracyjnego, [w:] System prawa administracyjnego, red. J. Starościak, t. 1, Wrocław 1977, s. 65. Poglądy doktryny prawa administracyjnego na przymiot domniemania prawidłowości decyzji administracyjnej są podzielone. Zob. na ten temat B. Adamiak, Wadliwość decyzji administracyjnej, Wrocław 1986, s. 24 n. i podana tam literatura.

2 B. Adamiak, [w:] B. Adamiak, J. Borkowski, Kodeks postępowania administracyjnego. Komentarz, Warszawa 2017, s. 58.

3 Ustawa z dnia 14 czerwca 1960 r. - Kodeks postępowania administracyjnego (tekst jedn. Dz.U. z 2017 r. poz. 1257; dalej: k.p.a.). 


\section{MIEJSCE MILCZĄCEGO ZAŁATWIENIA SPRAWY WE WŁADCZYM DZIAŁANIU ADMINISTRACJI PUBLICZNEJ}

W obowiązującym systemie prawa oprócz władczego działania administracji publicznej, kształtującego uprawnienia jednostki decyzją administracyjną, wprowadzana jest konstrukcja prawna czynności materialnoprawnej jednostki. Przykładem nabycia uprawnienia czynnością materialnoprawną jednostki jest czynność zgłoszenia, utrzymana tradycyjnie w ustawie z dnia 7 lipca 1994 roku. Prawo budowlane ${ }^{4}$. Nabycie uprawnienia do wykonania robót budowlanych przez inwestora enumeratywnie wyliczonych w art. 30 ust. 1 ustawy Prawo budowlane następuje na podstawie skutecznie dokonanej czynności materialnoprawnej zgłoszenia. Według art. 30 ust. 5 tej ustawy ,Zgłoszenia, o którym mowa w ust. 1, należy dokonać przed terminem zamierzonego rozpoczęcia robót budowlanych. Organ administracji architektoniczno-budowlanej, w terminie 21 dni od dnia doręczenia zgłoszenia, może, w drodze decyzji, wnieść sprzeciw. Do wykonywania robót budowlanych można przystąpić, jeżeli organ administracji architektoniczno-budowlanej nie wniósł sprzeciwu w tym terminie". Skuteczność prawną czynności materialnoprawnej inwestora wzmacnia regulacja w art. 30 ust. 5aa ustawy Prawo budowlane, zgodnie z którą „Organ administracji architektoniczno-budowlanej może z urzędu, przed upływem terminu, o którym mowa w ust. 5, wydać zaświadczenie o braku podstaw do wniesienia sprzeciwu. Wydanie zaświadczenia wyłącza możliwość wniesienia sprzeciwu, o którym mowa w ust. 6 i 7, oraz uprawnia inwestora do rozpoczęcia robót budowlanych". W zakresie działalności gospodarczej można wskazać na skuteczność czynności wniosku o wpis do rejestru. Według art. 64 ust. 1 ustawy z dnia 2 lipca 2004 roku o swobodzie działalności gospodarczej $^{5}$,,Jeżeli przepis odrębnej ustawy stanowi, że dany rodzaj działalności jest działalnością regulowaną w rozumieniu niniejszej ustawy, przedsiębiorca może wykonywać tę działalność, jeżeli spełnia szczególne warunki określone przepisami tej odrębnej ustawy i po uzyskaniu wpisu w rejestrze działalności regulowanej, z zastrzeżeniem art. 75”. Zgodnie z art. 65 ust. 1 tej ustawy „Organ prowadzący, na podstawie przepisów regulujących daną działalność gospodarczą, rejestr działalności regulowanej dokonuje wpisu na wniosek przedsiębiorcy, po złożeniu przez przedsiębiorcę oświadczenia o spełnieniu warunków wymaganych do wykonywania tej działalności”. Skuteczność czynności złożenia wniosku jest obwarowana zachowaniem terminu do dokonania czynności materialnotechnicznej przez organ prowadzący rejestr, przesądzając o skuteczności czynności przedsiębiorcy. Według art. 67 ustawy o swobodzie działalności gospodarczej „Organ prowadzący rejestr działalności regulowanej jest obowiązany dokonać wpisu przedsiębiorcy do tego rejestru w terminie 7 dni od dnia wpływu do tego organu wniosku o wpis

\footnotetext{
4 Tekst jedn. Dz.U. z 2017 r. poz. 1332 ze zm.

5 Tekst jedn. Dz.U. z 2016 r. poz. 1829 ze zm.
} 
wraz z oświadczeniem o spełnieniu warunków wymaganych do wykonywania działalności gospodarczej, dla której rejestr jest prowadzony (ust. 1). Jeżeli organ prowadzący rejestr działalności regulowanej nie dokona wpisu w terminie, o którym mowa w ust. 1, a od dnia wpływu wniosku do tego organu upłynęło $14 \mathrm{dni}$, przedsiębiorca może rozpocząć działalność [...] (ust. 2)".

Czynności materialnoprawnej zgłoszenia, na podstawie której inwestor nabywa uprawnienia do wykonywania robót budowlanych, przysługuje domniemanie prawidłowości po upływie ustawowego terminu do wniesienia decyzją przez organ architektoniczno-budowlany sprzeciwu czy po wystawieniu zaświadczenia. To domniemanie prawidłowości może obalić organ nadzoru budowlanego (art. 50 ust. 1 pkt 3 ustawy Prawo budowlane). W skuteczności wniosku o wpis do rejestru podjęcie działalności po upływie terminu do dokonania wpisu przez organ może mieć następstwa wydania przez organ prowadzący rejestr działalności regulowanej decyzji o zakazie wykonywania przez przedsiębiorcę działalności objętej wpisem, gdy na przykład przedsiębiorca złożył oświadczenie, o którym mowa w art. 65, niezgodne ze stanem faktycznym (art. 71 ust. 1 pkt 1 ustawy o swobodzie działalności gospodarczej).

Ustawa z dnia 7 kwietnia 2017 r. o zmianie ustawy — Kodeks postępowania administracyjnego wyznaczyła milczącemu załatwieniu sprawy określone miejsce $^{6}$ we władczym działaniu administracji publicznej ${ }^{7}$. Miejsce, które nie tworzy nowego zakresu przedmiotowego sprawy indywidualnej, lecz pozostaje w związku $\mathrm{z}$ rozstrzygnięciem sprawy indywidualnej w wyniku decyzji administracyjnej w postępowaniu administracyjnym, regulowanym przepisami k.p.a. Ten ścisły związek milczącego załatwienia sprawy z decyzją administracyjną wynika z regulacji uznania sprawy za załatwioną milcząco. Zgodnie z art. 122a § 2 k.p.a. „Sprawę uznaje się za załatwioną milcząco w sposób w całości uwzględniający żądanie strony, jeżeli w terminie miesiąca od dnia doręczenia żądania strony właściwemu organowi administracji publicznej albo innym terminie określonym w przepisie szczególnym organ ten: 1) nie wyda decyzji lub postanowienia kończącego postępowanie w sprawie (milczące zakończenie postępowania) albo 2) nie wniesie sprzeciwu w drodze decyzji (milcząca zgoda)". Milczące załatwienie sprawy wyznaczają przepisy materialnego prawa administracyjnego i to w podwójnym aspekcie. Pierwszy aspekt - milczące załatwienie sprawy jest przyjęte, tylko gdy przepisy materialnego prawa administracyjnego przyjmują rozstrzygnięcie sprawy

6 Dz.U. poz. 935.

7 B. Adamiak, [w:] B. Adamiak, J. Borkowski, Kodeks postepowania administracyjnego, s. 645, 646. Zob. też eadem, [w:] B. Adamiak, J. Borkowski, Postępowanie administracyjne i sądowoadministracyjne, Warszawa 2017, s. 305 n.; W. Sawczyn, Milczace załatwienie sprawy, [w:] System Prawa Administracyjnego, t. 9. B. Adamiak et al., Prawo procesowe administracyjne, Warszawa 2017, s. 206 n. i podana tam literatura; P. Dańczak, [w:] W. Chróścielewski, J.P. Tarno, P. Dańczak, Postęowanie administracyjne i postępowanie przed sadami administracyjnymi, Warszawa 2018, s. 213, 214. 
decyzją administracyjną (art. 122a § 2 pkt 1 k.p.a.) oraz w zakresie regulacji przepisami materialnego prawa czynności materialnoprawnej jednostki kształtującej jej uprawnienia, której skuteczność obwarowana jest przesłanką zgłoszenia sprzeciwu przez organ administracji publicznej w drodze decyzji administracyjnej (art. 122a $\S 2$ pkt 2 k.p.a.). Drugi aspekt to ograniczenie milczącego załatwienia sprawy do regulacji przepisami materialnego prawa administracyjnego, w których expressis verbis zawarta jest norma prawna dopuszczająca przyjęcie milczącego załatwienia sprawy. Zakres rodzaju spraw indywidualnych rozstrzyganych decyzją administracyjną, w których dopuszczalne jest milczące załatwienie sprawy, wyznaczają przepisy materialnego prawa administracyjnego. Mowa o tym w art. 122a $\S 1$ k.p.a.: „Sprawa może być załatwiona milcząco, jeżeli przepis szczególny tak stanowi”.

W regulacji prawnej k.p.a. zawarta jest oprócz postępowania zwykłego regulacja nadzwyczajnych trybów postępowania oraz regulacja środków prawnych wobec ostatecznych decyzji, które w wyniku przeprowadzenia kontroli przez organ administracji publicznej ich wykonania przez stronę podlegają wyeliminowaniu z obrotu prawnego. Przepisy k.p.a. w tym przedmiocie przyjmują rozstrzygnięcia w decyzji administracyjnej. Nie są jednak podstawą do wyprowadzenia dopuszczalności milczącego załatwienia sprawy pozbawienia mocy prawnej decyzji administracyjnej. Wyłączone jest expressis verbis milczące załatwienie sprawy w sprawie rozstrzygnięcia $\mathrm{w}$ trybie wznowienia postępowania (art. 151 § 3 k.p.a.), w sprawie w trybie stwierdzenia nieważności (art. 158 § 1 k.p.a.), w sprawie w trybie uchylenia, zmiany decyzji prawidłowej lub dotkniętej wadliwością niekwalifikowaną (art. 155a k.p.a.) oraz w sprawach podważenia mocy prawnej decyzji, uregulowanych $\mathrm{w}$ art. 161-163 k.p.a. (art. 163a k.p.a.).

\section{ZGODNOŚĆ Z PRZEPISAMI PRAWA MILCZĄCEGO ZAŁATWIENIA SPRAWY}

Regulacja milczącego załatwienia sprawy przepisami k.p.a. daje podstawy do wyróżnienia:

- po pierwsze, braku podstaw do przyjęcia milczącego załatwienia sprawy, a tym samym rozważenia zgodności z prawem. Jeżeli przepis szczególny w ustawie materialnoprawnej nie dopuszcza milczącego załatwienia sprawy i z upływu ustawowego terminu do załatwienia sprawy przez organ administracji publicznej nie wyda decyzji, występuje bezczynność organu. Bezczynność organu administracji publicznej jest stanem niezgodnym z prawem, podlegającym zaskarżeniu ponagleniem (art. 37 § 1 k.p.a.);

- po drugie, dopuszczalne jest przepisem szczególnym milczące załatwienie sprawy. Tylko w tym drugim zakresie należy rozważać zgodność z prawem milczącego załatwienia sprawy. 
Regulacja milczącego załatwienia sprawy przepisami k.p.a., tak jak o tym stanowi art. 1 pkt 1 k.p.a. oraz ścisłe powiązanie z rozstrzygnięciem sprawy indywidualnej decyzją administracyjną, oznacza, że mają zastosowanie zasady ogólne postępowania administracyjnego, w tym zasada praworządności. Milczące załatwienie sprawy musi być zgodne z obowiązującym porządkiem prawnym. To, że w art. 6 k.p.a., tak jak w art. 7 Konstytucji Rzeczypospolitej Polskiej, stanowi, że „Organy administracji publicznej działają na podstawie przepisów prawa”, nie oznacza, że milczące załatwienie sprawy jest wyłączone ze związania zasadą praworządności. Należy jednak wskazać na zasadnicze różnice w stosowaniu prawa przy rozstrzygnięciu sprawy decyzją administracyjną i przy milczącym załatwieniu sprawy. Rozpoznanie i rozstrzygnięcie sprawy indywidualnej w decyzji administracyjnej opiera się na procesie stosowania przepisów prawa materialnego i przepisów prawa procesowego przez organ administracji publicznej. W wyni$\mathrm{ku}$ autorytatywnej konkretyzacji normy materialnego prawa administracyjnego w ustalonym stanie faktycznym sprawy organ administracji publicznej wyprowadza konsekwencje prawne w rozstrzygnięciu decyzji administracyjnej. Natomiast milczące załatwienie sprawy związane jest $\mathrm{z}$ treścią żądania strony. Zgodnie z art. 122a $§ 2$ k.p.a. „Sprawę uznaje się za załatwioną milcząco w sposób w całości uwzględniający żądanie strony”. Nie ma podstaw do przyjęcia, że złożenie żądania przez stronę, a w następstwie milczące załatwienie sprawy, jest wynikiem autorytatywnej konkretyzacji normy materialnego prawa administracyjnego do ustalonego stanu faktycznego, dające podstawę do uwzględnienia w całości żądania strony i wyprowadzenia żądanych konsekwencji w zakresie jej uprawnienia. To, że zgodnie z art. 83 Konstytucji Rzeczypospolitej Polskiej „Każdy ma obowiązek przestrzegania prawa Rzeczypospolitej Polskiej”, nie oznacza, że złożone żądanie mieści się $\mathrm{w}$ obowiązującym porządku prawnym, ale też nie oznacza, że się w nim nie mieści.

Skutek prawny milczącego załatwienia sprawy przez wejście do obrotu prawnego powiązany jest z niezachowaniem przez organ administracji publicznej terminu miesiąca od dnia doręczenia żądania strony właściwemu organowi administracji publicznej lub innego terminu określonego w przepisie szczególnym, wydania decyzji lub postanowienia kończącego postępowanie w sprawie, wniesienia sprzeciwu w drodze decyzji. Wyprowadzenie mocy obowiązującej skutku prawnego milczącego załatwienie sprawy następuje przez ustalenie dnia wydania decyzji, o czym stanowi art. 122a $§ 2$ k.p.a. w związku z art. 122b k.p.a. Zgodnie z art. 122b k.p.a. „Za dzień wydania decyzji lub postanowienia kończącego postępowanie w sprawie, o której mowa $\mathrm{w}$ art. 122a $\S 2$ pkt 1, albo wniesienia sprzeciwu, o którym mowa w art. 122a § 2 pkt 2, uznaje się dzień: 1) nadania sprzeciwu, decyzji lub postanowienia kończącego postępowanie w sprawie za pokwitowaniem przez operatora pocztowego w rozumieniu ustawy z dnia 23 listopada 2012 r. Prawo pocztowe albo 2) doręczenia za pokwitowaniem sprzeciwu, decyzji lub postanowienia kończącego postępowanie w sprawie przez pracowników organu 
administracji publicznej lub inne upoważnione osoby, albo 3) wprowadzenia sprzeciwu, decyzji lub postanowienia kończącego postępowanie w sprawie do systemu teleinformatycznego w przypadku, o którym mowa w art. $39^{1}$ albo art. 392". Artykuł $122 \mathrm{c} \S 1$ k.p.a. normuje wejście do obrotu prawnego milczącego załatwienie sprawy, stanowiąc, że „Milczące załatwienie sprawy następuje w dniu następującym po dniu, w którym upływa termin przewidziany do wydania decyzji lub postanowienia kończącego postępowanie w sprawie albo wniesienia sprzeciwu. W przypadku gdy organ przed upływem terminu do załatwienia sprawy zawiadomi stronę o braku sprzeciwu, milczące załatwienie sprawy następuje w dniu doręczenia tego zawiadomienia". Nadanie przymiotu ostatecznego załatwienia sprawy reguluje art. $122 \mathrm{~g}$ in fine k.p.a. „Przyjmuje się, że skutek wydania decyzji ostatecznej powstał w terminie czternastu dni od dnia upływu terminu, o którym mowa w art. $122 \mathrm{c} \S 1$ ".

Przepisy k.p.a. dają organowi administracji publicznej kompetencje do rozpoznania i rozstrzygnięcia sprawy decyzją administracyjną w ustawowym terminie. Niewydanie decyzji w tak zakreślonym terminie, gdy przepis szczególny tak stanowi, powoduje wygaśnięcie kompetencji organu administracji publicznej na rzecz milczącego załatwienia sprawy. Milczące załatwienie sprawy obowiązuje $\mathrm{w}$ obrocie prawnym, korzystając $\mathrm{z}$ domniemania prawidłowości ${ }^{8}$.

Gwarancją prawną mocy obowiązującej milczącego załatwienia sprawy jest ustanowienie sankcji nieważności decyzji administracyjnej wydanej w sprawie załatwionej milcząco. Według art. $156 \S 1$ pkt 3 k.p.a. „Organ administracji publicznej stwierdza nieważność decyzji, która: dotyczy sprawy już poprzednio rozstrzygniętej inną decyzją ostateczną albo sprawy, którą załatwiono milcząco".

\section{OBALENIE DOMNIEMANIA PRAWIDŁOWOŚCI MILCZACEEGO ZAŁATWIENIA SPRAWY}

Związanie zasadą praworządności w postępowaniu administracyjnym rozpoznawania i rozstrzygania spraw administracyjnych $w$ decyzji administracyjnej (art. 6 k.p.a.) powoduje przyjęcie rozwiązań prawnych zawierających gwarancje prawne jej realizacji. Ustanowiona w pierwszej normie prawnej art. 7 k.p.a. zasada ogólna kontroli i nadzoru nad przestrzeganiem prawa w postępowaniu stanowi: „W toku postępowania organy administracji publicznej stoją na straży praworządności”. Z tego rozwiązania wynika obowiązek podjęcia czynności oceny, czy żądanie rozpoznania i rozstrzygnięcia sprawy w decyzji administracyjnej mieści się $\mathrm{w}$ istniejącym porządku prawnym podstaw do dokonania autorytatywnej konkretyzacji normy materialnego prawa administracyjnego. Brak podstaw prawnych w materialnym prawie administracyjnym do rozstrzygnięcia sprawy w decyzji

8 Zob. W. Sawczyn, op. cit., s. 218, 219. 
zamyka dopuszczalność wszczęcia postępowania w sprawie. Organ administracji publicznej obowiązany jest w wyniku takiej oceny żądania wydać postanowienie o odmowie wszczęcia postępowania (art. 61a $\S 1$ k.p.a.). Niedokonanie takiej oceny $\mathrm{w}$ formie postanowienia otwiera skutecznie wszczęcie postępowania w sprawie i w następstwie w razie niewydania decyzji w ustawowym terminie, gdy przepis szczególny tak stanowi, milczące załatwienie sprawy. Po upływie ustawowego terminu organ administracji publicznej właściwy w sprawie nie ma podstaw prawnych do kwestionowania treści rozstrzygnięcia. Przesądza o tym expressis verbis norma pierwsza art. 122a $\S 2$ k.p.a.: „Sprawę uznaje się za załatwioną milcząco w sposób w całości uwzględniający żądanie strony".

Wyłączenie właściwości organu administracji publicznej wkroczenia w treść milczącego załatwienie sprawy nie oznacza, że nie jest dopuszczalne podważenie domniemania prawidłowości. Z zasady ogólnej praworządności oraz zasady ogólnej kontroli i nadzoru nad przestrzeganiem prawa wynika obowiązek zarówno organu administracji publicznej, który był właściwy do rozpoznania i załatwienia sprawy, jak i organu wyższego stopnia do oceny zgodności z przepisami prawa nie tylko decyzji, lecz także milczącego załatwienie sprawy. Według art. 122g k.p.a.: „Do spraw załatwionych milcząco przepisy rozdziałów 12 i $13 \mathrm{w}$ dziale II stosuje się odpowiednio. Przyjmuje się, że skutek wydania decyzji ostatecznej powstał w terminie czternastu dni od dnia upływu terminu, o którym mowa w art. 122c $\S 1$ ".

Do obalenia domniemania prawidłowości decyzji stosuje się tryby nadzwyczajne ${ }^{9}$. Wprawdzie art. $16 \S 1$ k.p.a., stanowiąc: „Decyzje, od których nie służy odwołanie w administracyjnym toku instancji lub wniosek o ponowne rozpatrzenie sprawy, są ostateczne. Uchylenie lub zmiana takich decyzji, stwierdzenie ich nieważności oraz wznowienie postępowania może nastąpić tylko w przypadkach przewidzianych w kodeksie lub ustawach szczególnych", wyznacza granice domniemania prawidłowości ostatecznej decyzji administracyjnej, nie obejmując milczącego załatwienie sprawy, ale przez regulację zastosowania odpowiednio rozdziałów 12 i 13 działu II k.p.a. granice te w zasadzie się pokrywają. Artykuł $122 \mathrm{~g}$ k.p.a. stanowi bowiem o odpowiednim stosowaniu, a zatem z uwzględnieniem odrębności wynikającej z regulacji postępowania przy milczącym załatwieniu sprawy. Zgodnie z art. 122d § 1 k.p.a.: „Do spraw załatwianych milcząco nie stosuje się art. $10 \mathrm{i}$ art. 79d". Wyłącza to zastosowanie do milczącego załatwienia sprawy skutków, jakie przepisy prawa procesowego wiążą z naruszeniem prawa procesowego strony do czynnego udziału w postępowaniu i umocnieniem tego prawa strony przez nałożenie na organ administracji publicznej obowiązków zapewnienia realizacji tego prawa (art. 79a k.p.a.). Przesądzające znaczenie będzie miała regulacja w przepisach szczególnych wyznaczających rodzaje przedmiotowe spraw załatwianych milcząco.

9 B. Adamiak, Koncepcja wadliwości milczacego załatwienia sprawy, [w:] System Prawa Administracyjnego, t. 9, s. 295. 
Milczące załatwienie sprawy musi mieścić się w obowiązującym porządku prawnym, z tym że tak jak decyzja administracyjna korzysta $\mathrm{z}$ domniemania prawidłowości. Oznacza to, że może zostać wyeliminowane z obrotu prawnego z powodu wadliwości kwalifikowanej, Jeżeli jednak nie zostanie wyeliminowane, pozostaje w obrocie prawnym, jak też gdy dotknięta jest wadliwością niekwalifikowaną bądź gdy jest zgodna z prawem, ale względy celowości dostosowania do interesu społecznego czy słusznego interesu indywidualnego strony dają podstawę do uchylenia lub zmiany. Jeżeli jednak milczące załatwienie sprawy nie zostanie w obowiązującym trybie prawnym wyeliminowane, pozostaje w obrocie prawnym.

Kwalifikowane naruszenie przepisów postępowania, wyliczone enumeratywnie $\mathrm{w}$ art. 145, art. 145a $\S 1$, art. 145b $\S 1$ k.p.a., będące podstawą do wznowienia postępowania administracyjnego w sprawie zakończonej ostateczną decyzją, jest podstawą do wznowienia postępowania zakończonego ostatecznie milczącym załatwieniem sprawy. Odpowiednie zastosowanie wynika z konieczności uwzględnienia odrębności regulacji procesowej, tak jak podkreślono przez wyłączenie stosowania art. $10 \mathrm{i}$ art. 79a k.p.a. wprost $\mathrm{w}$ art. $122 \mathrm{~d} \S 1$ k.p.a., ale też te odrębności będą wynikały z regulacji w przepisach szczególnych. Do takich wadliwości procesowej wyliczonej w art. $145 \S 1$ k.p.a. należy wskazać milczące załatwienie sprawy na podstawie fałszywych dowodów przesądzających o istotnych okolicznościach stanu faktycznego sprawy (pkt 1), milczące załatwienie sprawy w wyniku przestępstwa (pkt 2), naruszenie przepisów o wyłączeniu pracownika, organu administracji publicznej, członka organu kolegialnego (pkt 3), wyjście na jaw istotnych dla sprawy okoliczności faktycznych lub nowych dowodów istniejących w dniu milczącego załatwienia sprawy (pkt 5), milczące załatwienie sprawy objęte było procedurą współdziałania (pkt 6), milczące załatwienie sprawy było rozstrzygnięciem zależnym od decyzji lub orzeczenia sądu, które zostało następnie uchylone lub zmienione (pkt 8). Nie będzie miała zastosowania przesłanka wyliczona w pkt 7 art. $145 \S 1$ k.p.a. ze względu na to, że jeśli występuje w sprawie zagadnienie wstępne, organ administracji publicznej obowiązany jest zawiesić postępowanie (art. $97 \S 1$ pkt 4 k.p.a.). Zawieszenie postępowania administracyjnego wstrzymuje bieg ustawowego terminu załatwienia sprawy (art. 122d $\S 2$ k.p.a.). Rozstrzygnięcie zagadnienia wstępnego przez właściwy organ administracji publicznej nakłada na organ obowiązek podjęcia zawieszonego postępowania i rozstrzygnięcia sprawy decyzją administracyjną w ustawowym terminie, z odliczeniem okresu zawieszenia postępowania. Milczące załatwienie sprawy nie może nastąpić przed upływem terminu ustawowego z odliczeniem okresu zawieszenia postępowania. Nie można wykluczyć wznowienia postępowania na podstawie przesłanek wyliczonych w art. $145 \mathrm{a} \S 1$ i art. $145 \mathrm{~b} \S 1$ k.p.a. Ma to znaczenie dla ograniczenia dopuszczalności wznowienia postępowania z urzędu. O ile obowiązująca zasada ogólna kontroli i nadzoru nad przestrzeganiem praworządności daje podstawy wszczęcia postępowania w sprawie wznowienia postępowania $\mathrm{z}$ urzędu przez organ, który nie załatwił sprawy w postępowaniu w pierwszej instancji, ale też przez organ wyższe- 
go stopnia oraz na żądanie strony, o tyle w przypadkach wyliczonych w art. 145a $\S 1$ i art. 145b $\S 1$ k.p.a. wszczęcie postępowania wznowieniowego w sprawie zakończonej milcząco może nastąpić wyłącznie na żądanie strony.

Do wznowienia postępowania w sprawie załatwionej milcząco właściwy jest organ administracji publicznej pierwszej instancji, chyba że przyczyną wznowienia postępowania jest działalność tego organu. Do przyczyn tych zaliczyć należy wyłączenie organu, wyłączenie pracownika organu, którzy nie wyłączyli się po złożeniu żądania przez stronę (art. $145 \S 1$ pkt 3 k.p.a.), jeżeli fałsz dowodów lub inne przestępstwo (na przykład łapówka) pozostaje w związku z milczącym załatwieniem sprawy (art. $145 \S 1$ pkt 1 i 2 k.p.a.). Uchylenie lub odmowa uchylenia milczącego załatwienia sprawy następuje w wyniku decyzji. Obalenie prawidłowości milczącego załatwienia sprawy w trybie wznowienia postępowania następuje wyłącznie w decyzji. Przepisów o milczącym załatwieniu sprawy do podważenia mocy domniemania prawidłowości milczącego załatwienia sprawy nie stosuje się (art. 122g w związku z art. 151 § 1 i 3 k.p.a.).

Kwalifikowane naruszenie przepisów prawa materialnego, wyliczone enumeratywnie w art. $156 \S 1$ k.p.a., dające podstawę do zastosowania sankcji nieważności decyzji administracyjnej, jest też podstawą do zastosowania sankcji nieważności milczącego załatwienia sprawy. Obalenie domniemania prawidłowości milczącego załatwienia sprawy może zatem nastąpić w trybie postępowania w sprawie stwierdzenia nieważności decyzji. Przypisanie przez organ administracji publicznej właściwości do załatwienia sprawy mimo niewystępowania ku temu podstaw prawnych, co w konsekwencji doprowadziło do utraty kompetencji przez organ właściwy ze względu na milczące załatwienie sprawy, powoduje, że milczące załatwienie sprawy jest dotknięte ciężkim, kwalifikowanym naruszeniem prawa. Niezałatwienie sprawy w ustawowym terminie przez organ administracji publicznej, choć nie był właściwym w sprawie, ale nie dokonał czynności nakazanych prawem: nie przekazał podania organowi właściwemu (art. $65 \S 1$ k.p.a.) czy nie zwrócił podania stronie (art. $66 \S 3$ k.p.a.), czego następstwem jest milczące załatwienie sprawy, daje podstawę do stwierdzenia nieważności milczącego załatwienia sprawy. Wprawdzie w regulacji milczącego załatwienia sprawy przyjmuje się wyprowadzenie milczącego załatwienia sprawy, gdy żądanie strony zostało doręczone właściwemu organowi administracji publicznej, ale niezastosowanie przez organ przewidzianych przepisami prawa czynności z powodu ustalenia braku właściwości powoduje uznanie właściwości, a w następstwie milczące załatwienie sprawy.

Milczące załatwienie sprawy musi pozostawać w zgodzie z regulacją materialnego prawa administracyjnego $\mathrm{w}$ zakresie podstawy prawnej rozstrzygnięcia sprawy decyzją administracyjną i treści regulacji w zakresie uprawnienia lub obowiązku. Milczące załatwienie sprawy może być zatem dotknięte dwojakiego rodzaju kwalifikowanym naruszeniem normy materialnego prawa administracyjnego:

— po pierwsze, braku podstawy prawnej milczącego załatwienia sprawy; — po drugie, rażącym naruszeniem prawa. 
Milczące załatwienie sprawy jest podwójnie ograniczone w zakresie podstawy prawnej. Pierwsze ograniczenie wynika z regulacji w przepisie prawa materialnego formy rozstrzygnięcia sprawy przez przyjęcie formy decyzji administracyjnej, drugie wynika też z regulacji przepisu prawa materialnego, który expressis verbis stanowi o dopuszczalności milczącego załatwienia sprawy. Brak takiej regulacji powoduje, że nie ma podstawy prawnej milczącego załatwienia sprawy, a to zgodnie $\mathrm{z}$ art. $156 \S 1$ pkt 2 k.p.a. obwarowane jest sankcją nieważności.

Drugim rodzajem kwalifikowanego naruszenia przepisu prawa materialnego jest rażące naruszenie prawa milczącym załatwieniem sprawy. Rażące naruszenie prawa może mieć aspekt przedmiotowy oraz aspekt podmiotowy. Rażące naruszenie prawa $\mathrm{w}$ aspekcie przedmiotowym wystąpi, gdy treść żądania pozostaje w sprzeczności z treścią normy prawnej niewywołującej wątpliwości interpretacyjnej, gdy treść żądania dotyczy sprawy rozstrzygniętej decyzją ostateczną, treść żądania jest obwarowana cechą niewykonalności, a ta niewykonalność ma charakter trwały, gdy treść żądania w razie wykonania powodowałaby czyn zagrożony karą, treść żądania obwarowana jest sankcją nieważności z mocy prawa. Rażące naruszenie prawa w aspekcie podmiotowym będzie występowało, gdy żądanie zostało wniesione przez jednostkę niebędącą stroną w sprawie bądź jest skierowane na uprawnienie lub obowiązek jednostki, która nie jest stroną w sprawie.

Właściwym do wszczęcia z urzędu postępowania w sprawie stwierdzenia nieważności i w następstwie obalenia domniemania prawidłowości milczącego załatwienia sprawy przez zastosowanie sankcji nieważności jest organ wyższego stopnia, chyba że przepis szczególny dopuści milczące załatwienie sprawy w postępowaniu zwykłym przez ministra lub samorządowe kolegium odwoławcze, wówczas właściwe będą te organy (art. 157 § 1 k.p.a.). Z żądaniem stwierdzenia nieważności może wystąpić też strona, a zwłaszcza ta, której następstwa prawne milczącego załatwienie sprawy dotyczą.

Zastosowanie sankcji nieważności milczącego załatwienie sprawy może nastąpić wyłącznie w formie decyzji. Zgodnie z art. $158 \S 1$ k.p.a. „Rozstrzygnięcie w sprawie stwierdzenia nieważności decyzji następuje w drodze decyzji. Przepisów o milczącym załatwieniu sprawy nie stosuje się". Artykuł 122g k.p.a., odsyłając do odpowiedniego zastosowania przepisów regulujących postępowanie w sprawie stwierdzenia nieważności decyzji, przesądza, że postępowanie w sprawie stwierdzenia nieważności milczącego załatwienia sprawy kończy decyzja stwierdzająca nieważność milczącego załatwienia sprawy lub odmawiająca stwierdzenia nieważności.

Do obalenia domniemania prawidłowości milczącego załatwienia sprawy zastosowanie mają przesłanki wyłączające zastosowania sankcji wzruszalności w trybie wznowienia postępowania (art. $146 \S 1$ i 2 k.p.a.), a w postępowaniu w sprawie stwierdzenia nieważności milczącego załatwienia sprawy przesłanki wyłączające dopuszczalność stosowania sankcji nieważności (art. $156 \S 2$ k.p.a.). W takich przypadkach te tryby nadzwyczajne kończy rozstrzygnięcie decyzja stwierdzają- 
ca, że milczące załatwienie sprawy narusza prawo. Milczące załatwienie sprawy pozostaje w obrocie prawnym.

Obalenie domniemania prawidłowości milczącego załatwienia sprawy może nastąpić w trybie nadzwyczajnego postępowania w sprawie uchylenia lub zmiany decyzji dotkniętej wadliwością niekwalifikowaną. Zgodnie z art. 122a $§ 1$ k.p.a. sprawę uznaje się za załatwioną milcząco w sposób w całości uwzględniającej żądanie strony. Jeżeli milczące załatwienie sprawy w całości uwzględnia żądanie strony, to do podważenia domniemania prawidłowości zastosowanie będzie miała regulacja uchylenia, zmiany decyzji ostatecznej tworzącej prawa dla strony. Według art. 155 k.p.a.: „Decyzja ostateczna, na mocy której strona nabyła prawo, może być w każdym czasie za zgodą strony uchylona lub zmieniona przez organ administracji publicznej, który ją wydał, jeżeli przepisy szczególne nie sprzeciwiają się uchyleniu lub zmianie takiej decyzji i przemawia za tym interes społeczny lub słuszny interes strony; przepis art. $154 \S 2$ stosuje się odpowiednio”. Jeżeli są spełnione przesłanki ustanowione w art. 155 k.p.a., a zatem zgoda strony (stron), a przepis szczególny temu się nie sprzeciwia, może nastąpić przez organ, który właściwy był do rozpoznania i rozstrzygnięcia sprawy, uchylenie lub zmiana treści milczącego załatwienia sprawy. Uchylenie lub zmiana milczącego załatwienia sprawy następuje w formie decyzji administracyjnej (art. 122g w związku z art. 155a k.p.a.).

Wyeliminowanie z obrotu prawnego milczącego załatwienia sprawy następuje nie tylko przez obalenie prawidłowości, lecz także milczące załatwienie sprawy podlega kontroli organu administracji publicznej z punktu widzenia ochrony interesu publicznego, prawidłowego realizowania treści milczącego załatwienia sprawy. Zgodnie z art. $161 \S 1$ k.p.a., który z mocy art. 122g k.p.a. ma zastosowanie do milczącego załatwienia sprawy, minister, a w wyznaczonym zakresie wojewoda, może uchylić lub zmienić w niezbędnym zakresie milczące załatwienie sprawy, jeżeli w inny sposób nie można usunąć stanu zagrażającemu życiu lub zdrowiu ludzkiemu albo zapobiec poważnym szkodom dla gospodarki narodowej lub ważnych interesów państwa. Wymaga to formy decyzji (art. 122g w związku z art. 163a k.p.a.). Organ administracji publicznej kontroluje wykonanie milczącego załatwienia sprawy i w razie stwierdzenia, że milczące załatwienie sprawy stało się bezprzedmiotowe, stwierdza wygaśnięcie mocy milczącego załatwienia sprawy (art. 122g w związku z art. $162 \S 1$ pkt 1 k.p.a.). Podstawą do uchylenia lub zmiany milczącego załatwienia sprawy mogą być też przepisy szczególne (art. 122g w związku z art. 163 k.p.a.).

\section{TRWAŁOŚĆ MILCZĄCEGO ZAŁATWIENIA SPRAWY}

Milczące załatwienie sprawy wchodzi do obrotu prawnego w dniu następnym po dniu, w którym upływa termin przewidziany do wydania decyzji lub postanowienia kończącego postępowanie w sprawie albo wniesienia sprzeciwu (art. 122c 
$\S 1$ k.p.a.). Milczące załatwienie sprawy nabywa przymiot ostatecznego załatwienia sprawy. Zgodnie bowiem z art. 122g in fine k.p.a. „Przyjmuje się, że skutek wydania decyzji ostatecznej powstał w terminie czternastu dni od dnia upływu terminu, o którym mowa w art. 122c $\S 1$ ".

Milczące załatwienie sprawy obowiązuje w obrocie prawnym, wiążąc zarówno organ administracji publicznej, jak i stronę (strony). Milczące załatwienie sprawy korzysta $\mathrm{z}$ ochrony trwałości, obowiązując w obrocie prawnym jako rozstrzygnięcie sprawy zgodne z przepisami prawa. Podważenie trwałości milczącego załatwienia sprawy może nastąpić przez obalenie domniemania prawidłowości na podstawie przepisów prawa w trybach przewidzianych dla weryfikacji decyzji i w wyniku kontroli wykonania decyzji mających zastosowanie do milczącego załatwienia sprawy (art. 122g k.p.a.).

Obowiązywanie w obrocie prawnym milczącego załatwienia sprawy wyłącza dopuszczalność rozpoznania i rozstrzygnięcia sprawy decyzją ostateczną. Rozpoznanie i rozstrzygnięcie sprawy decyzją administracyjną przed wyeliminowaniem z obrotu prawnego milczącego załatwienia sprawy jest podstawą stwierdzenia jej nieważności (art. $156 \S 1$ pkt 3 k.p.a.). Tworzy to gwarancję prawną obowiązywania w obrocie prawnym jako zgodnego z prawem milczącego załatwienia sprawy.

\section{PRESUMPTION OF THE CORRECTNESS OF THE SILENT DEALING WITH THE CASE}

\section{Summary}

The silent dealing with the case enters into legal circulation on the day following the day on which the time limit stipulated for issuing the decision or ruling terminating the proceedings in the case or raising objections expires (Article 122c $\S 1$ of the Code of Administrative Procedure). The silent dealing with the case acquires the aspect of the final dealing with the case. According to art. 122g in fine of the Code of Administrative Procedure "It is assumed that the effect of issuing the final decision was made within fourteen days from the date of expiry of the deadline referred to in art. $122 \mathrm{C} \S 1$." The silent dealing with the case is valid in the legal circulation, binding both the public administration bodies and the party (parties). The silent dealing with the case benefits from the protection of durability, being legally binding as a solution to the case in accordance with the law. Undermining the durability of a silent dealing can be done by rebutting the presumption of correctness based on the law in the procedures provided for verifying the decision, as well as a result of an inspection of the enforcement of the decisions applicable to the silent dealing with the case (Article 122g of the Code of Administrative Procedure).

Keywords: silent dealing with the case, presumption of the correctness, durability, limits of durability, modes of verification 


\section{BIBLIOGRAFIA}

Adamiak B., Koncepcja wadliwości milczacego załatwienia sprawy, [w:] System Prawa Administracyjnego, t. 9. B. Adamiak et al., Prawo procesowe administracyjne, Warszawa 2017.

Adamiak B., Wadliwość decyzji administracyjnej, Wrocław 1986.

Adamiak B., Borkowski J., Kodeks postępowania administracyjnego. Komentarz, Warszawa 2017.

Adamiak B., Borkowski J., Postepowanie administracyjne i sadowoadministracyjne, Warszawa 2017.

Borkowski J., Określenie administracji i prawa administracyjnego, [w:] System prawa administracyjnego, red. J. Starościak, t. 1, Wrocław 1977.

Chróścielewski W., Tarno J.P., Dańczak P., Postępowanie administracyjne i postępowanie przed sadami administracyjnymi, Warszawa 2018.

Sawczyn W., Milczace załatwienie sprawy, [w:] System Prawa Administracyjnego, t. 9. B. Adamiak et al., Prawo procesowe administracyjne, Warszawa 2017. 